\title{
Zdenko Babić
}

ORCID: 0000-0002-3896-8688

Zagreb University

Faculty of Law ${ }^{1}$

Josip Lučev

ORCID: 0000-0002-4393-0334

Libertas International University ${ }^{2}$

\section{Comparative analysis of economic and social policy development in Croatia and Slovenia}

\section{Summary}

The Republic of Croatia and the Republic of Slovenia have shared a common political and economic history for centuries. Slovenia was more developed but was relatively closely trailed by Croatia in basic economic and social indicators as recently as the late 1980s. In the intervening three decades, the economic and social inequalities between Croatia and Slovenia have significantly increased and these two countries are in many ways at opposite ends of the spectrum among the members of the EU. This text acknowledges

${ }^{1}$ Correspondence: Zdenko Babić, Zagreb University, Faculty of Law, Nazorova 51, 10000 Zagreb, Croatia; author's email address: zbabic@pravo.hr

2 Correspondence: Josip Lučev, Libertas International University, Trg J. F. Kennedy 6b, 10000 Zagreb; author's email address: jlucev@libertas.hr 
the traditional explanations of this result-i.e. the negative effect of the Homeland War in Croatia between 1991 and 1995 its human and economic sacrifices which were enormous compared to the very brief and limited conflict in Slovenia; and that Slovenia became a full member of the EU in 2004, whereas Croatia could reap the benefits of EU membership since only 2013. However, this text moves beyond these two arguments and proposes that there are additional explanatory variables for divergent tendencies in economic and social development. It analyses the institutional positions in Croatia and Slovenia (comparing them to the Visegrád countries), the growth models in Slovenia and Croatia, and the way in which social policy was delivered since the transition in Slovenia and Croatia in order to show that a significant part of the explanation for these downward divergent trends in Croatia lies within the way these two main policies were prepared and implemented in those two countries.

Key words: post-socialist economies, Slovenia, Croatia, institutional reforms, social policy

\section{Introduction}

The Republic of Croatia and the Republic of Slovenia share a common socialist history within the former Yugoslavia. Slovenia was the most developed part of this former state but was relatively closely trailed by Croatia in basic economic and social indicators. At the beginning of the 1990s, both states achieved independence. Almost three decades have passed and the economic and social inequalities between Croatia and Slovenia have significantly increased. In the last ten years Slovenia is among the EU countries with the lowest poverty risk rates-in stark contrast with Croatia, which is on the other end of the spectrum and is counted amongst the worst performers. Slovenia has also slightly increased its population while Croatia has lost around $5 \%$ of its population in the last ten years. Texts of some authors in Croatia suggest that these increases in economic and social inequalities between Slovenia and Croatia could be ascribed to the negative effect of the Homeland War in Croatia between 1991 and 1995 (Bićanić, Franičević, 2005; Vojnić, 2013; Družić, 2009), the human and economic sacrifices of which were enormous compared to Slovenia, where independence was achieved through a very brief and limited conflict (i.e. the Ten-Day War). Another argument which can often be found is the fact that Slovenia became a full member of the EU in 2004, while Croatia could reap the benefits of EU membership since only 2013. For instance, estimates show that investments from cohesion policy programmes raised annual GDP 0.8\% in Slovenia during the 2007-2013 programming period (European Commission, 2014, p. 232).

Even though these two arguments are valid, our paper proposes that there are additional explanatory variables for divergent tendencies in economic and social development. We will start by offering the necessary context by providing a brief economic history of Slovenia and Croatia in the next section. We continue with the analysis of basic institutional positions in Croatia and Slovenia (comparing them to the Visegrád countries) 
in section "Institutions of capitalism in Slovenia and Croatia", and the supply-side and demand-side analysis of growth models of Slovenian and Croatian economies in section "Growth models in Croatia and Slovenia". Section "Social policy developments and social effects" will examine the way in which social policy was delivered since the transition in Slovenia and Croatia. It surveys differences in inequality, poverty, social protection expenditure and the effects of social transfers, and concludes that a significant part of the explanation for these downward divergent trends in Croatia lies within the way in which these two main policies were prepared and implemented in those two countries. The last concludes and detects an optimistic opportunity for the future development of social policy in Croatia.

\section{Brief economic history of Croatia and Slovenia}

Slovenia and Croatia are countries which have formed in the context of a shared political history. With certain minor exceptions, these two countries were parts of the same political entities starting in 1527 and ending only in $1991^{3}$. The twentieth century brought several political and economic shocks: With the end of World War I, Slovenia and Croatia ceased to be parts of the Austro-Hungarian Empire and were integrated into the new Kingdom of Serbs, Croats and Slovenes (which was to become the Kingdom of Yugoslavia). This meant they shifted very quickly from the position of relative backwardness in the context of the Austro-Hungarian Empire to being the most developed, industrialized and financially developed parts of the new state, particularly as the new political centre in Serbia was economically decimated by the war (ŠimončićBobetko, 2005, pp. 15-50). The interwar business cycle downturns were relatively severe in Yugoslavia and the political differences were brought to a head when King Alexander I stopped the democratic experiment of the initial period and effectively turned the country into a dictatorship in 1929. World War 2 brought not only an economic shock of the highest order (with the country occupied and local puppet-governments set up in some areas-most notably in what is today Croatia and Bosnia and Herzegovina) but also destruction of war at a scale unseen theretofore. After WWII, Yugoslavia re-emerged in the form of a socialist country, which was, however, singular amongst other European socialist countries in several relevant elements.

Firstly, politically, it began moving away from Moscow in 1948 (and closer to the West, including military aid and with continued membership in the IMF). Secondly, it performed several waves of market-oriented reforms, as well as introduced a very strong economic and political position of the federal republics. The result was an unusual hybrid which joined areas with (still) markedly different levels of development into a common, one-

3 These minor exceptions are the areas controlled by the Ottomans (e.g. Slavonia region of Croatia in the $16^{\text {th }}$ and $17^{\text {th }}$ century), by the Republic of Venice (intermittent control of western Slovenia and Istria and Dalmatia regions of Croatia until the fall of the Republic of Venice in 1797), the specific and independent position of Dubrovnik until its fall in 1806 as well as the turbulent war eras of the Napoleonic period and WWII, both of which brought temporary rewritings of borders. 
party socialist country, with substantially more market organization than other socialist economies. While some semblance of policies of cohesion were in place in order to bridge the rampant developmental differences, the economic divergence would persist throughout the duration of Yugoslavia.

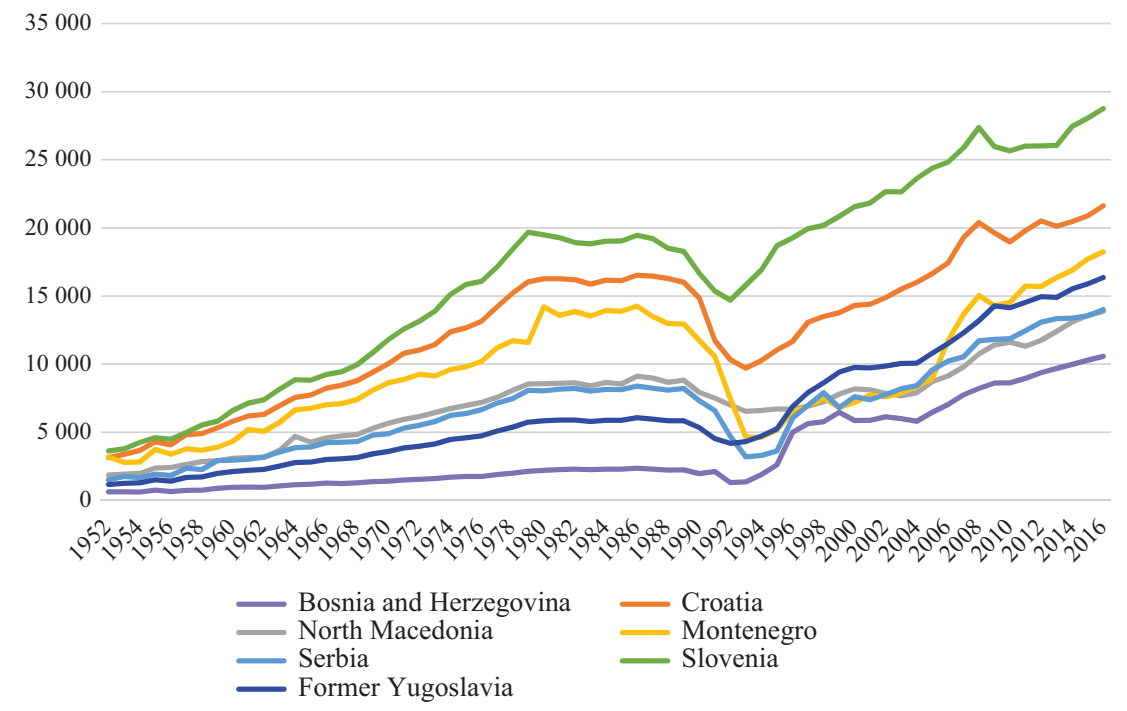

Graph 1. GDP per capita in Yugoslav republics and in Yugoslav successor states

Source: Maddison Project (2018). Apart from the six states shown in the graph (Bosnia and Herzegovina, Croatia, North Macedonia, Montenegro, Serbia and Slovenia), Kosovo is today another de facto successor of Yugoslavia, albeit a legally disputed one. Sadly, however, the Maddison database does not carry the data for Kosovo which would enable us to include it here.

GDP per capita is the most basic and accessible measure of development. Graph 1 uses the 2018 version of the Maddison database (the most recent) to compare these levels in Croatia to other republics, including Slovenia, which were a part of Yugoslavia. We have used the $c g d p p c$ variable which attempts to achieve comparable data both through time and across countries by using multiple price benchmarks to correct for price levels and express the GDP per capita data in 2011 USD (Bolt et al., 2018). In terms of development levels, we can see that Socialist Yugoslavia had clearly delineated clubs of good performers (Croatia, Slovenia and to a certain degree, Montenegro) and of relatively underdeveloped republics (Bosnia and Herzegovina, Macedonia and Serbia).

Focusing on the relationship between Slovenia and Croatia, we see Slovenia performing somewhat better for the majority of the Yugoslavia period and at its very end, in 1990, Croatian GDP per capita was at $89 \%$ of the Slovene GDP per capita. However, 1991 brought the beginning of another very destructive war in Croatia (Homeland War), while Slovenia won its independence at a far lower cost (the so called "Ten Day War"). In only three years, by 1993, the Croatian GDP per capita was to stand at a mere $61.5 \%$ of the 
Slovene level and it would bottom out at 59.1\% at the war's end in 1995. Intervening years would be spent in alleviating this dramatic fall, and in 2016, this level would reach $75.2 \%$ (Maddison Project, 2018; own calculation).

While this can be hailed as a Croatian success story in terms of a partial recovery of the developmental ground lost, such an account would clearly obscure the fact that Croatia and Slovenia both managed to lose roughly a decade of economic growth as a consequence of the 2008-2009 economic crisis and that Croatia tends to bring up the rear of EU member states in many relevant economic and social indicators. This paper will use this historical context as a backdrop for posing the relevant questions on the disappointing economic and social developments in Croatia, and we will argue Slovenia provides us with a useful comparison. The next section will first open the question of the differences in basic market (or capitalism) institutions in Croatia and will offer a partial comparison with the four post-socialist Visegrád economies as well.

\section{Institutions of capitalism in Slovenia and Croatia}

In the past twenty years, the dominant paradigm of comparative capitalism research has proven to be the approach of Varieties of Capitalism (Nölke, 2016; 2019). It has demonstrated sufficient versatility for the eventual inclusion of post-socialist economies, even though its simplistic categorical structure left much to be desired. While often criticized, the success of this approach has made it a ubiquitous starting point for comparative market-economy analysis. Within this approach, the precondition for economic success of any given country is not any single institutional solution, but rather a consistent approach throughout the political economy cutting through finance, labour markets, education, inter-firm relations etc. The better the externalities of a regulatory solution are exploited by other regulatory solutions, the more successful is the economy (Hall, Soskice, 2001; Hall, Gingerich, 2009). Varieties of capitalism focused on two versions of developed capitalism: the coordinated market economy (CME) as a restrictively regulated variety of capitalism (Scandinavian countries, Germany, Austria, Switzerland, Belgium, Netherlands and Japan) and the liberal market economy (LME) as a flexible variety oriented in the direction of free markets (USA, Canada, Ireland, UK, Australia and New Zealand). CMEs develop systems for the formation of specific skills, protected and organized labour markets, and long-term bank-centric corporate governance systems. LMEs base their institutional comparative advantage on formation of general skills, flexible labour markets with low unionization, and short term oriented corporate governance with predominant stock-market financing.

This approach has been criticized primarily for its ideal-typical simplicity, limited number of countries covered by its model, and constrictive micro-economic focus (e.g. Streeck, 2010; Becker, 2007), and has spawned at least two significant generations of research attempting to overcome these limitations (Nölke, 2016). As we have shown elsewhere (Lučev, Babić, 2013), this growing body of work has attempted to use the categorical apparatus of Varieties of Capitalism on the post-socialist countries in Central 
and Eastern Europe and has often placed Slovenia squarely in the CME camp. Croatia has more seldomly been analysed, but we have argued that the main institutions are generally similar to the CME variety and that the fault for a discouraging growth lies elsewhere (ibid). Table 1 shows an overview of relevant indicators in two salient institutional areas: labour market and finance organization (somewhat misleadingly treated under the header of corporate governance in the "varieties of capitalism" tradition). We compare Slovenia and Croatia against Visegrád countries to illustrate the differences.

Table 1. Selected indicators for labour and finance organization

\begin{tabular}{|c|c|c|c|}
\hline Indicator/Economy & Croatia & Slovenia & Visegrád \\
\hline Union density & $20.2 \%(2018)$ & $20.4 \%(2016)$ & $\begin{array}{l}\text { Czechia } 11.5 \%(2018) \\
\text { Hungary } 7.9 \%(2018) \\
\text { Poland } 14 \%(2016) \\
\text { Slovakia 10.7\% (2016) } \\
\text { Visegrád avg-11\% }\end{array}$ \\
\hline $\begin{array}{l}\text { Collective bargaining } \\
\text { coverage }\end{array}$ & $44.2 \%(2017)$ & $70.9 \%(2016)$ & $\begin{array}{l}\text { Czechia 30.4\% (2016) } \\
\text { Hungary 20.5\% (2017) } \\
\text { Poland 15.8\% (2015) } \\
\text { Slovakia 30\% (2015) } \\
\text { Visegrád avg-24.2\% }\end{array}$ \\
\hline $\begin{array}{l}\text { Collective bargaining } \\
\text { centralization }\end{array}$ & $\begin{array}{l}\text { Alternating between } \\
\text { the company and } \\
\text { the sectoral level ( } 2 \text { ) }\end{array}$ & $\begin{array}{l}\text { Predominantly } \\
\text { sectoral level (3) }\end{array}$ & $\begin{array}{l}\text { Hungary, Poland-predomi- } \\
\text { nantly company level (1) } \\
\text { Czechia, Slovakia-alternat- } \\
\text { ing between the company } \\
\text { and the sectoral level (2) }\end{array}$ \\
\hline $\begin{array}{l}\text { Stock market \% GDP } \\
\text {-10-year average }\end{array}$ & $38.3 \%$ & $15.2 \%$ & $\begin{array}{l}\text { Slovakia } 5.1 \% \\
\text { Hungary } 17.2 \% \\
\text { Poland } 33 \% \text { a }\end{array}$ \\
\hline $\begin{array}{l}\text { Bank credit to domestic } \\
\text { private sector \% GDP } \\
\text {-10-year average }\end{array}$ & $65.1 \%$ & $63.6 \%$ & $\begin{array}{l}\text { Slovakia } 51.3 \% \\
\text { Poland } 51.4 \% \\
\text { Hungary } 45.5 \% \\
\text { Czechia } 49.6 \%\end{array}$ \\
\hline $\begin{array}{l}\text { Stock market-banking } \\
\text { sector ratio }\end{array}$ & 0.59 & 0.24 & $\begin{array}{l}\text { Slovakia } 0.1 \\
\text { Poland } 0.64 \\
\text { Hungary } 0.38\end{array}$ \\
\hline $\begin{array}{l}\text { Stock traded as \% GDP } \\
-10 \text {-year average }\end{array}$ & $1.1 \%$ & $1 \%$ & $\begin{array}{l}\text { Slovakia } 0.3 \% \\
\text { Poland } 12.1 \% \\
\text { Czechia } 8.7 \% \\
\text { Hungary } 10 \% \text { b }\end{array}$ \\
\hline
\end{tabular}

a Data for Czechia is not available, and the data for Slovakia is available only until 2013.

b Data for Czechia is not available since 2015, and the data for Slovakia is not available since 2014. Sources: Visser, 2019; World Bank, 2019; own calculation. 
In terms of the labour market organization, Croatia and Slovenia have experienced declines in organizational capacity, but still remain above the levels found in the four Visegrád economies. In Croatia, this deterioration of the labour organization is primarily visible in the severe drop of union density from $38 \%$ in 2003 to $30.3 \%$ in 2008 and $20.2 \%$ in 2018. Slovenia experienced a similar, but even more precipitous fall from $47 \%$ in 2002 to $30.6 \%$ in 2007 and $20.4 \%$ in 2016. When compared to Visegrád, these figures are still substantially above the average of $11 \%$. The level at which collective bargaining takes place is highest in Slovenia (mostly sectoral), intermediate in Croatia, Czechia and Slovakia (combination of sectoral and company-level bargaining) and decentralized in Poland and Hungary (predominantly company-level bargaining). Collective bargaining coverage (i.e. the result of the previous two indicators) also shows these trends. It is the highest in Slovenia at $70.9 \%$ (a remnant of a relatively recent far more centralized arrangements), noticeably lower in Croatia at $44.2 \%$, but lower still in all Visegrád economies averaging at $24.2 \%$ (Visser, 2019).

The data on financial markets shows an interesting moment. We have shown the data on the size of market capitalization (as a proxy for stock-market orientation typical for LME economies) and the data on domestic credit issued by banks (as a proxy for bank orientation typical for CME economies) and averaged it for the last ten years to reduce the effects of market volatility. The ratios of these two indicators put all of the countries in the CME camp as banking is substantially more structurally important than stock markets. The figures on the banking sector are highest for Croatia $(65.1 \%$ of GDP) and Slovenia (63.6\%) and somewhat lower in Visegrád economies (averaging at $49.5 \%$ ). Croatia has the structurally largest stock-market by this account standing at $38.3 \%$, followed by Poland (33\%), with Hungary and Slovenia at substantially lower levels and Slovakia at the lowest end (with data for Czechia not available). However, when we account for the volumes of stocks actually traded, we see that these figures are very low not only in Slovakia ( $0.3 \%$ of GDP), but also in Croatia (1\%) and Slovenia $(1.1 \%)$ and are shadowed by figures in Czechia (8.7\%), Hungary (10\%) and Poland (12.1\%). All of this suggests that the Polish stock market is the most developed, balancing a significant size with a significant trade volume.

In any event, all of this would put both Croatia and Slovenia in a similar position concerning their basic coordination institutions, and yet Croatian economic performance failed to re-converge with Slovenia following the war. The reasons are not only economic and structural (next section), but also largely political and institutional. Increasingly, the fault for the Croatian inefficiency is found in a clientelistic institutional framework (Franičević, 2002; Cvijanović, Redžepagić, 2011; Stubbs, Zrinščak, 2015; Petak, 2019; Šimić Banović, 2019). These are wide-spread networks by which meritocracy is essentially circumvented and replaced by various particularistic personal connections. The overall effect is difficult to assess by analysing official statistics. While official laws and institutions are very visible, clientelist institutions join corruption on the informal institutional side of the institutional cleavage or even within the activities for circumventing both formal and informal institutions (North, 1991). This opacity is, instead, penetrated when its 
deficiencies are dramatically exposed. An example was the collapse of the Agrokor business empire, which some authors treat as a part of a Croatian form of crony capitalism (Ivanković, 2017). The result is an economy particularly vulnerable to state capture and to the development of an oversized and under-efficient public administration. The Croatian share of civil servants in government employment is the largest in the EU and at more than four times the share of Slovenia (Thijs et al., 2018, p. 22), which is important as it awards another level of job security to government employees, tending to underscore their immunity to efficiency.

\section{Growth models in Croatia and Slovenia}

This section will analyse the structural aspects of Croatian and Slovene economies by comparing the supply side (added value by sector as \% GDP) and demand side (source of demand as \% GDP) of both economies.

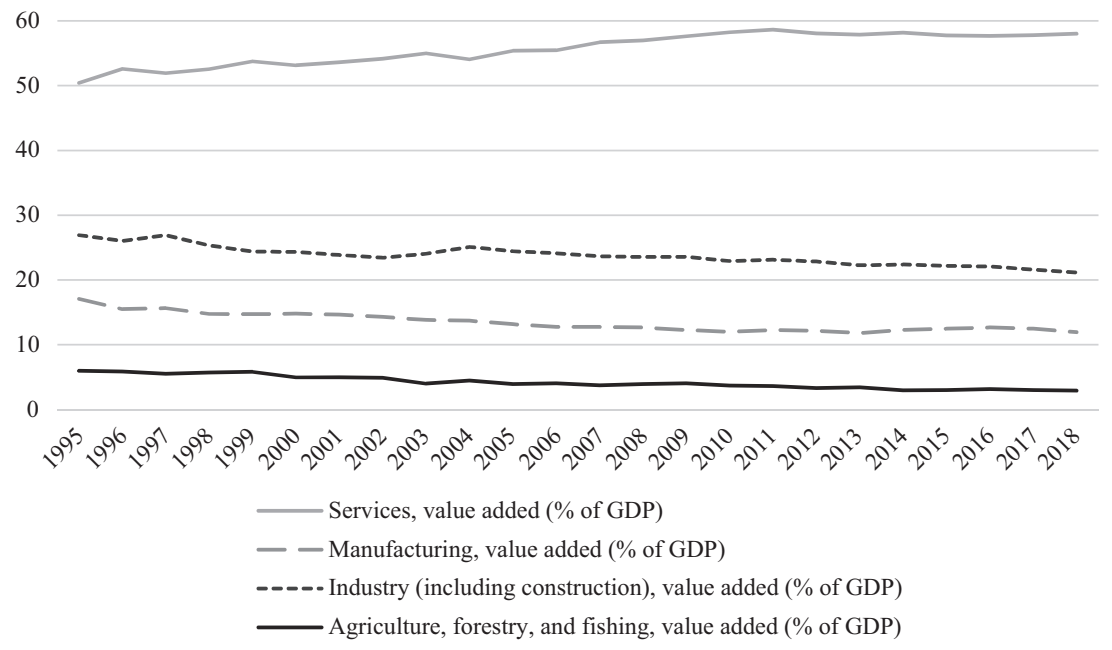

\section{Graph 2. Croatian growth model-supply side}

Source: World Bank, 2019.

Graph 2 shows the trends in the supply side of the Croatian growth model. All four indicators shown are expressed as value added in terms of \% of GDP, reflecting the structural value (i.e. compared to the size of the economy) of net output of each sector. Services (tertiary sector) dominate this comparison, rising from 50.4\% in 1995 to $58 \%$ GDP in 2018. The secondary sector is shown in the broader sense (industry) including construction and in the narrower sense (manufacturing), excluding construction. Both display signs of deindustrialization, with broader industry falling from 27\% in 1995 to $21.1 \%$ in 2018 and narrower manufacturing falling from $17 \%$ to $11.9 \%$ in the same period. Likewise, value added in the primary sector fell from 6 to $3 \%$ GDP. 


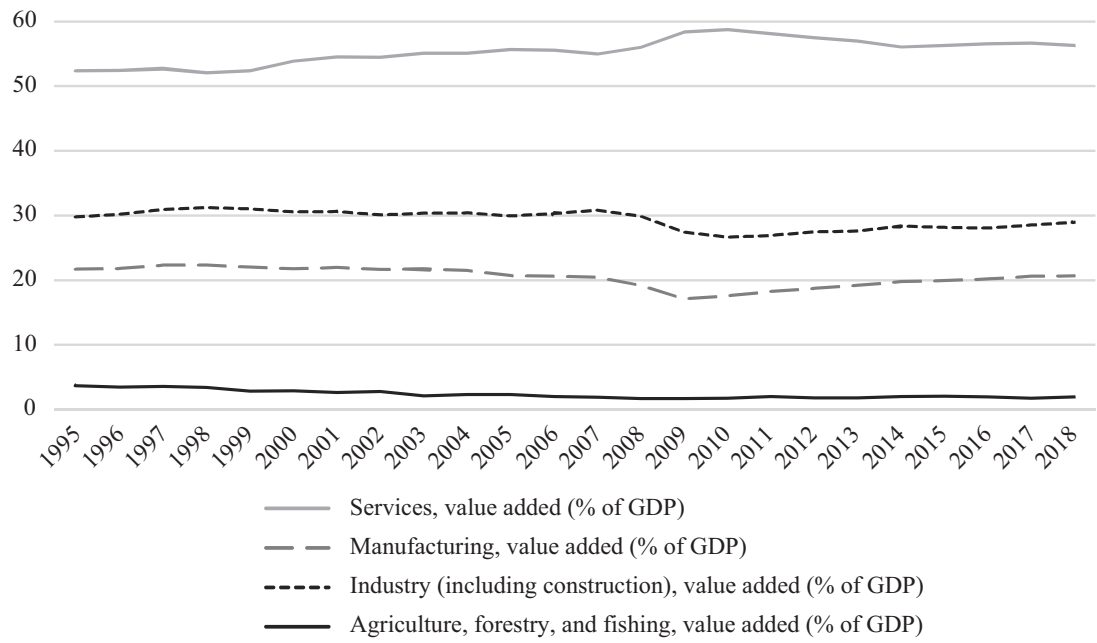

Graph 3. Slovenian growth model—supply side

Source: World Bank, 2019.

In Slovenia, these indicators followed a somewhat different dynamic. The structural value of net output in services grew from 52.4\% in 1995 to $58.7 \%$ in 2010 and then declined to $56.3 \%$ in 2018 . Both indicators of the secondary sector remained relatively stable, notwithstanding a sharp decrease in 2009 and a correction since then. Industry started at $29.8 \%$ in 1995 and finished at $28.9 \%$ in 2018, while the narrower manufacturing started at $21.7 \%$ in 1995 and finished at $20.7 \%$ in 2018. The net output of the primary sector slightly decreased from 3.7 to $1.9 \%$ GDP in the 23 years.

There are two significant differences in Croatia and Slovenia: firstly, the role of manufacturing is clearly different, with Croatia showing a deindustrialized perspective unlike Slovenia, and secondly, Slovenian output was more sensitive to the drop in GDP in 2009 with a drop in manufacturing accompanied by an increase in services. This suggests that manufacturing output decreased at a steeper rate than GDP (itself suffering a massive contraction), while output in services dropped at a slower rate than GDP in 2009. Likewise, the relative insensitivity of these patterns to the GDP contraction in Croatia suggests an aggregate drop in output was roughly in line with the GDP contraction. More significantly, a comparison of these structural output values with other countries shows the discrepancy between Slovenia and Croatia in an even more telling fashion. The current rate of net manufacturing output in Slovenia at $20.7 \%$ GDP is significantly above the average rates in the Euro area $(15.1 \%)$ or EU (14.1\%), highly developed economies like USA (11.2\%), UK (8.9\%), France $(9.9 \%)$ or even Sweden $(13 \%)$ and is similar to rates found in Germany $(20.8 \%)$, the Visegrád group (e.g. Poland at 18\%, Slovakia at $20 \%$, Hungary at $19.4 \%$ ), and, interestingly, Romania (20.1\%). The lower Croatian rate is comparable with the deindustrialized countries, suggesting a different role and power relations of its labour organization within the context of its industrial relations. 
Graph 4 puts the value added in services and in manufacturing for 2018 in context with several other market-economies.

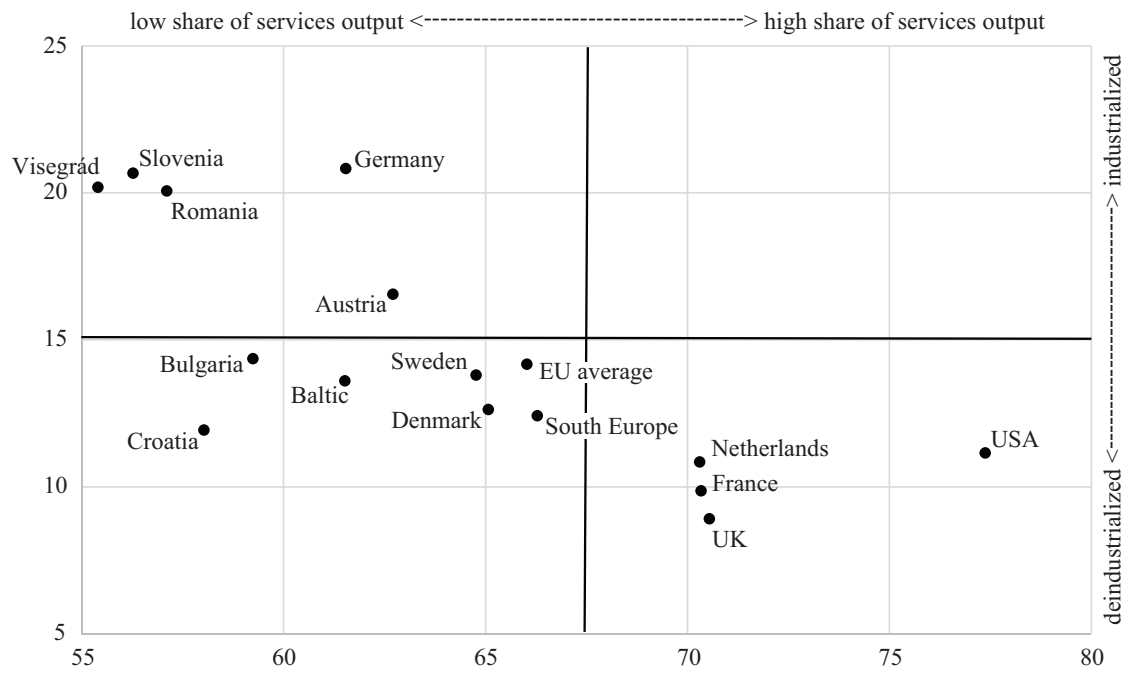

Graph 4. Structural aspects of the supply side growth models

Source: World Bank, 2019.

We have shown Visegrád, Baltic, and South European clusters as averages to avoid cluttering the graph. The $\mathrm{x}$ axis shows the levels of value added in services as $\%$ of GDP, while the y axis shows the value added in manufacturing as \% of GDP. We can see the average of Slovenia, Romania, and Visegrád grouped in relatively low value-added in services, but relatively high in manufacturing. USA, and to a lesser extent, Netherlands, France and UK are grouped opposite-with relatively low value-added in manufacturing, but relatively high value-added in services. Croatia seems to be positioned in a particularly unfavourable part of the graph. While the value-added in manufacturing is higher as a \% GDP than Netherlands or France, and value-added in services is higher than the levels found in Slovenia, Romania or the Visegrád average, the trade-off between the two seems less than optimal (i.e. low and left on the graph).

The demand side of the Croatian growth model is shown on graph 5, showing the four variables roughly representing the functional composition of GDP $(\mathrm{C}+\mathrm{I}+\mathrm{G}+\mathrm{Nx})$, with final consumption of households and nonprofit organizations serving households representing private consumption, gross capital formation representing investments, government expenditure, and current account balance serving as a rough measure of international trade (encompassing net trade in goods, services, as well as income transfers and direct investments), all of which are expressed as \% GDP. Private consumption experienced a steady decline from $66.5 \%$ in 1995 to $57.5 \%$ in 2018. Government expenditure has remained relatively stable (remaining in the $44-48 \%$ GDP since the late 
1990s), although the general trend has been one of a steady rise starting at $41.1 \%$ in 1995 and finishing at an estimated 47.2 in 2018. Investments consistently rose from $16.8 \%$ in 1995 to $31.4 \%$ in 2008, which was followed by a precipitous drop stabilizing since 2012 and reaching $21.4 \%$ in 2018. Finally, the current account balance presented the main challenge of Croatian growth. Despite a vibrant tourism sector (i.e. a substantial and continuous services export), the current account balance remained negative, with disturbingly large deficits in some years, notably -10.4 in 1997 and -8.6 in 2008. The crisis of 2008/09 had a number of extremely negative effects, although it managed to exert a correction in the current account balance, which not only achieved its first positive value since 1995 in 2013, but also reached a welcome $4.5 \%$ in 2015 and staying in relatively high values since with an estimated surplus of $2.9 \%$ in 2018.

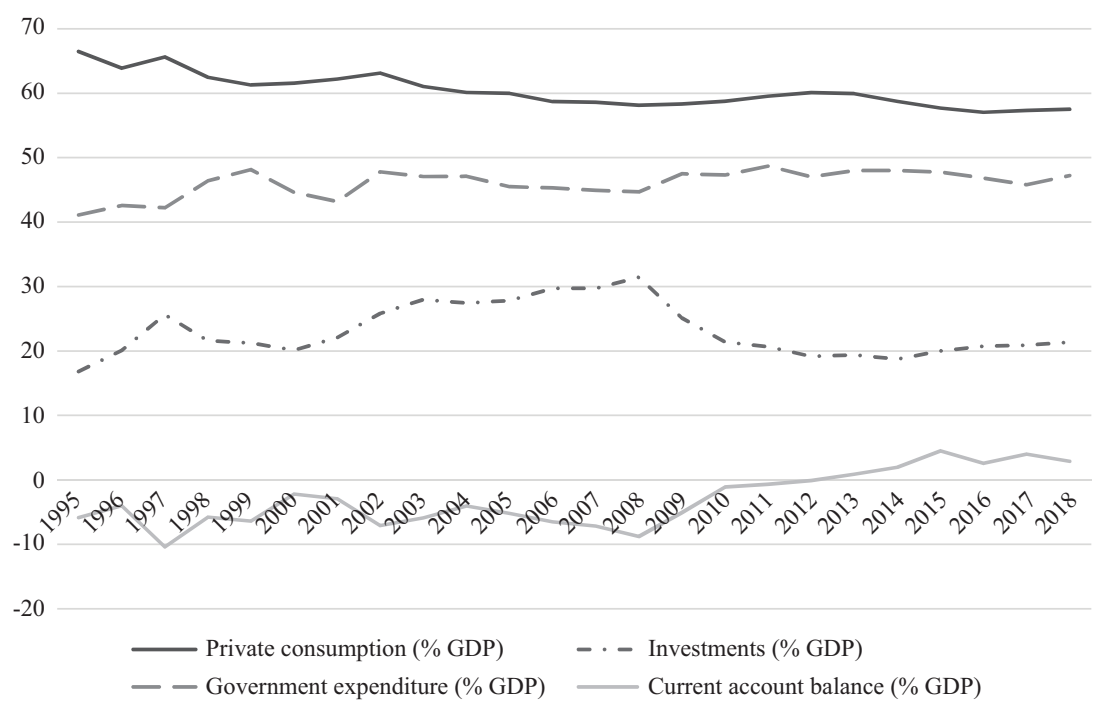

\section{Graph 5. Croatian growth model—demand side}

Source: Data on private consumption and investment (World Bank, 2019); data on government expenditure and current account balance (IMF, 2019).

The composition of demand in Slovenia has followed roughly similar trends with a few significant differences. The private consumption first fell from 59.2\% GDP in 1995 to $51.2 \%$ in 2008 and rose and fell through the next decade to stabilize at $50.8 \%$ in 2018 . Government expenditure remained relatively stable 1995-2008, mostly in the 39-42\% range, then increased for several years and spiked at a problematic 54.4\% GDP in 2013 to fall back to an estimated $39.3 \%$ in 2018. Investments grew from $25 \%$ in 1995 to $32.8 \%$ in 2007, only to drop significantly, and spending fell below 20\% in 2012-2016 period to finish at $21.9 \%$ in 2018. Current accounts suffered an increasing deficit in the late 1990s (reaching -3.2) and then again notably after 2002 until reaching -5.3 in 2008 after which it continuously corrected to an estimated $6.5 \%$ in 2018. 


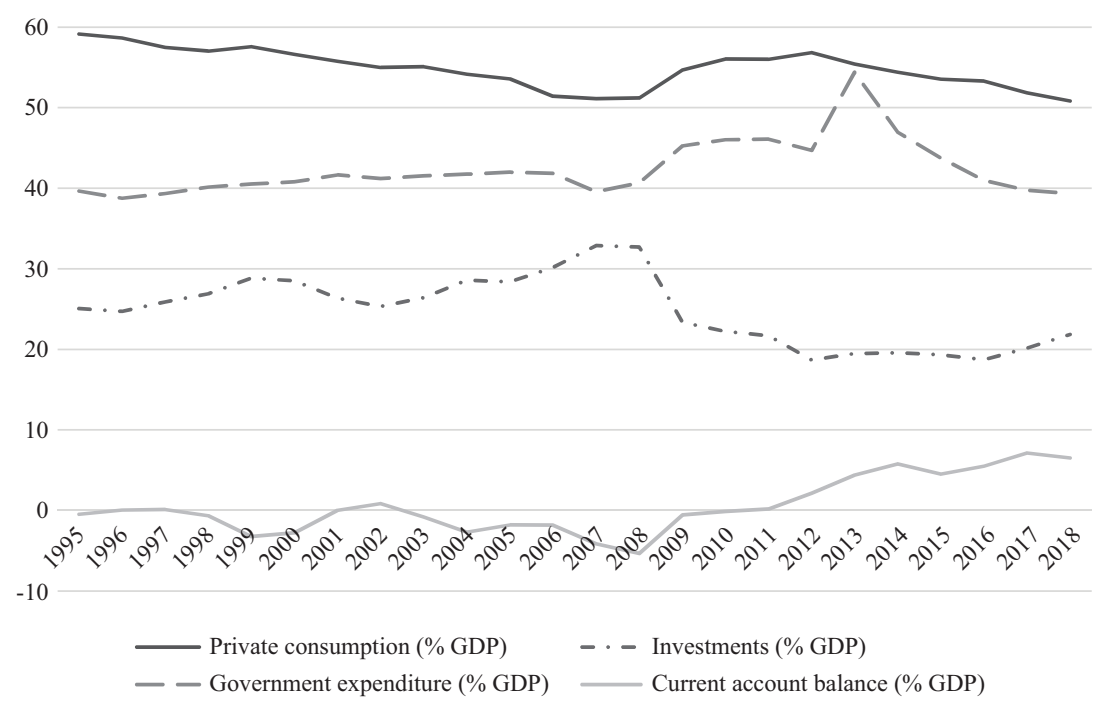

Graph 6. Slovenian growth model—demand side

Sources: Data on private consumption and investment (World Bank, 2019); data on government expenditure and current account balance (IMF, 2019).

This section has analysed the supply side and the demand side of Croatian and Slovenian growth models. Some similarities can be discerned, but there are also striking differences. The supply side analysis shows that Croatia has a significantly lower valueadded GDP ratio in industry, only slightly compensated by the higher share in services. This is significant as it is indicative of a somewhat hasty deindustrialization. Deindustrialization reduces the traditional manoeuvring space of trade unions in turn, as the strong industrial centres have structurally stronger trade unions which can exert a more significant pressure towards income equality. In a sense, this element provides an additional link between the previous section dealing with industrial relations and the next section dealing with social effects. The demand side analysis points to a higher role of consumption in Croatia, partially made feasible by the financing of the emigre worker community, as the levels of personal remittances to Croatia are exceedingly high for an EU member state 4 .

\section{Social policy developments and social effects}

The comparison to Eastern European economies is of a particular interest to us. According to Eurostat data on nominal GDP per capita development, Slovenia is still the most developed Eastern European country-as it was in 2008. Czech Republic and Estonia are at somewhat lower levels while Croatia was overtaken by Lithuania, Poland and Hungary in this ten-year interval, and among Eastern European EU members, only

4 4.74\% GDP in 2018, compared to $1.12 \%$ in Slovenia (World Bank, 2019). 
Romania and Bulgaria had a lower GDP per capita than Croatia in 2018. On the other hand, comparing Croatian GDP in 2018 to ex-Yugoslav countries still shows almost two times the level of Serbia, North Macedonia or Bosnia and Herzegovina (with Montenegro somewhat closer).

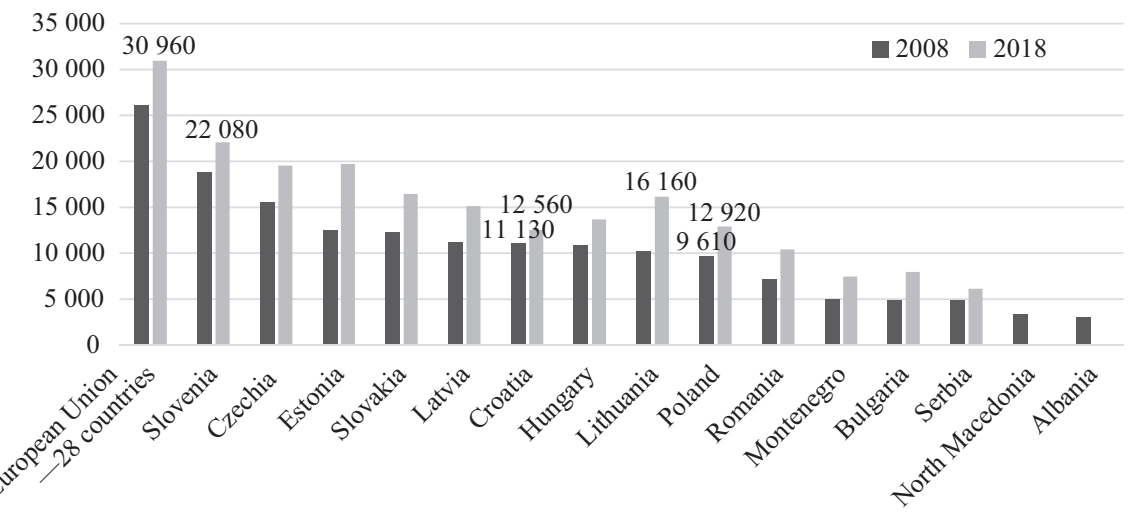

Graph 7. GDP per Capita (in EUR, current prices) Eastern European Countries

Source: Eurostat, 2019.

It is a clear from data depicted in Graph 7 that Croatia has lost its relative position and competitiveness compared to Eastern European EU member economies in the last ten years. At the same time the Slovenian economy showed much better performances (including social indicators like Gini coefficient, S80/S20, AROPE shown below). In the following part of the text we will turn to the analysis of that social development path in these two neighbouring countries.

Table 2. Economic inequalities in Croatia and Slovenia from 1993-2018

\begin{tabular}{|l|c|c|c|c|c|}
\hline \multicolumn{1}{|c|}{ Gini coefficient } & $\mathbf{1 9 9 3} / \mathbf{9 5} / \mathbf{1 9 9 8}$ & $\mathbf{2 0 0 0}$ & $\mathbf{2 0 0 8}$ & $\mathbf{2 0 1 0}$ & $\mathbf{2 0 1 8}$ \\
\hline Slovenia & $\begin{array}{l}24(1993) \\
27(1998)^{* *}\end{array}$ & 22 & 23.4 & 23.8 & 23.4 \\
\hline Croatia & $30^{*}$ & n.a & 27.0 & 31.5 & 29.7 \\
\hline
\end{tabular}

Source: Eurostat (2019) from 2000-2010; B. Milanović, (1998)5.

Table 2 and graphs 8 and 9 show the development of economic inequality in Slovenia and Croatia. We can observe that economic inequality in Croatia was significantly higher than in Slovenia from the beginning of the transition process.

5 http://www.umar.gov.si/fileadmin/user_upload/projekti/hdr2000.pdf 


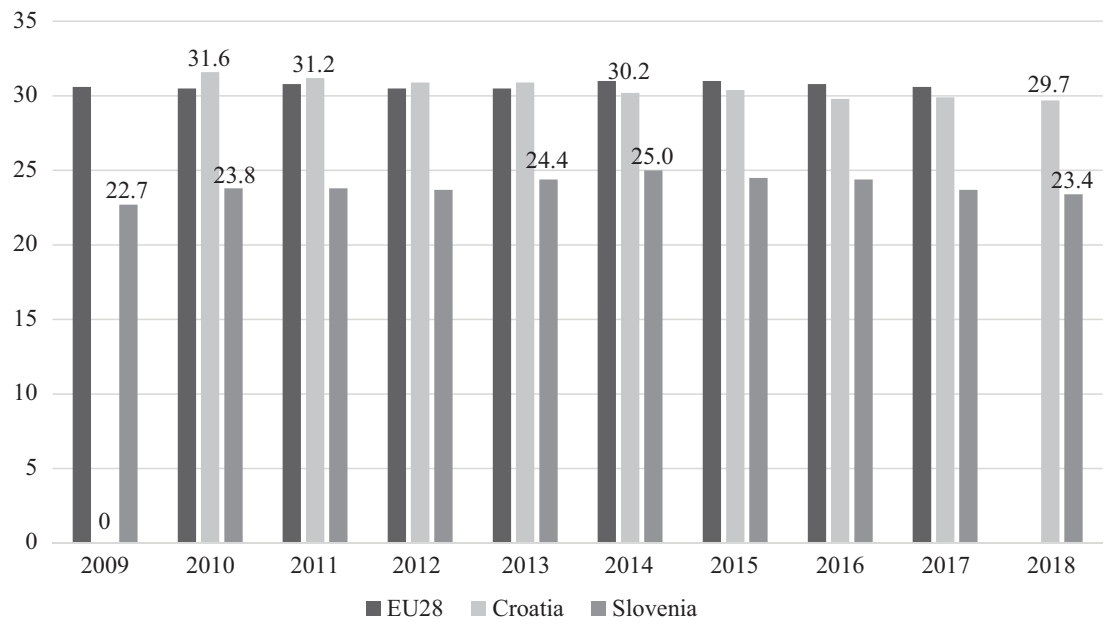

Graph 8. Gini coefficient dynamics in HR, SLO and EU 28

Source: Eurostat, 2019.

In the intervening years, these differences have increased and in 2018 economic inequalities in Croatia measured by Gini coefficient were 6.3 percentage points higher than in Slovenia. The same trend could be observed in S80/S20 ratio which showed that twenty percent of those with highest income have 5 times higher income than twenty percent of those at the bottom of income distribution in Croatia during last ten years while in Slovenia respective figure is below 3.5 .

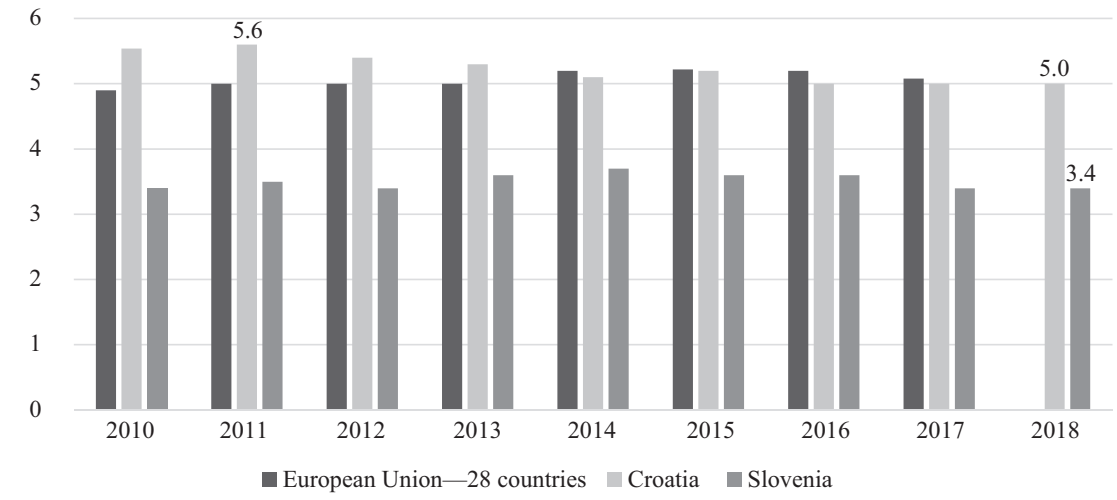

Graph 9. S80 /S20; 2010-2018 development in SLO and HR and EU28

Source: Eurostat, 2019.

Several explanations for these differences in economic inequality can be found in existent literature and they usually follow three main arguments. The first argument is that Slovenia implemented gradual transition reform not following the IMF and Washington 
consensus approach according (Hanžek, \& Gregorčić) while the Croatian privatization process was burdened with many problems (Rončević, 2001). Pragmatism and gradualism prevailed in Slovenia, relating both to economic policy and to changes in the economic system. The controversy of "shock therapy versus gradualism" was clearly expressed in the debates on privatization in Slovenia. The version of privatization which was implemented in Slovenia was gradual, decentralized, and slow as opposed to a massive, centralized, and distributive privatization (Mencinger, 2002) as suggested by the Washington consensus prescriptions and was advocated by some economic advisers at that time like Jeffrey Sachs and which was partially followed in Croatia. The second argument concerns another crucial aspect of the early transition process. Despite a decline in GDP and employment, Slovenia implemented strong social policy measures with increase in social benefits during the first year of transition that could be seen in a significant increase in social benefits share in total household income distribution from $16.2 \%$ in 1983 to $22.6 \%$ in 1993 and $29.7 \%$ in 1999 (see Rončević, 2001, p. 138). At the same time, Croatia was burdened with war and war related costs including refugee costs, financing reconstruction, and the rebuilding of destroyed homes and houses in the 1992-1998 period. The third usual argument points to relatively strong trade unions in Slovenia, higher trade union membership with relatively higher collective agreement coverage in Slovenia comparing with other CEE countries and Croatia (Holzner \& Leitner, 2008) for first period of transition until 2000.

On the other hand, from the Eurostat data presented, these differences in economic inequalities between Slovenia and Croatia remain stable until 2018 and some authors (Čok et al., 2013) studying Croatian and Slovenian tax and social benefits systems find that Slovenia continuously had lower pre-fiscal inequality than Croatia and a higher redistributive effect of the tax and social protection system. Namely, the same text (Čok et al., 2013) described that Slovenia has somewhat more progressive personal income tax than Croatia with four income brackets and from 2013 even five income brackets with rates of $16 \%, 27 \%, 34 \%, 39 \%$ and, since $2013,50 \%$ provides for some vertical equity. As the thresholds are set rather low, however, the majority of middle-class citizens fall into the second or third-highest category. On the other hand, Croatian 2017 tax reform worked to further decrease the three income brackets $(12 \% ; 25 \% ; 40 \%)$ to two income brackets $(24 \% ; 36 \%)$ and the effects of this change could slightly increase income inequality in Croatia. The redistributive effect stemming from social benefits could be explained by graph 12 which shows social protection expenditure as a share of GDP 2008-2018. It is a clear that Slovenia continuously registered higher social expenditure share in average higher than Croatia by more than 2 percentage points. These two points are the most important explanations for the trends in economic inequalities in Slovenia and Croatia after 2000s. It should be noted that the Croatian economic inequalities are in line with the EU28 average, but that Slovenia is among the best performing EU countries-i.e. amongst the economies with lowest inequalities. Authors of this text take the position that Slovenia provides a positive and useful example for the construction of policy prescriptions for Croatia. Firstly, Croatia should always compare with and learn from the best performing countries in EU, provided that they are sufficiently similar for 
a meaningful comparison. Bearing in mind that Croatia and Slovenia are two neighbouring countries with many cultural similarities, similar traditions and a long shared political history, and the exemplary Slovenian performance in the context of income inequality, Slovenia provides a useful benchmark.

These trends in economic inequality also have implications for poverty and social exclusion indicators, bearing in mind the relative methodology applied to measure the at risk of poverty rate in EU countries.

These indicators are presented in graphs 10 and 11 so it should be not surprising (having in mind inequality data) that Slovenia performs continuously and significantly better than Croatia with lower proportion of population exposed to poverty and social exclusion risks.

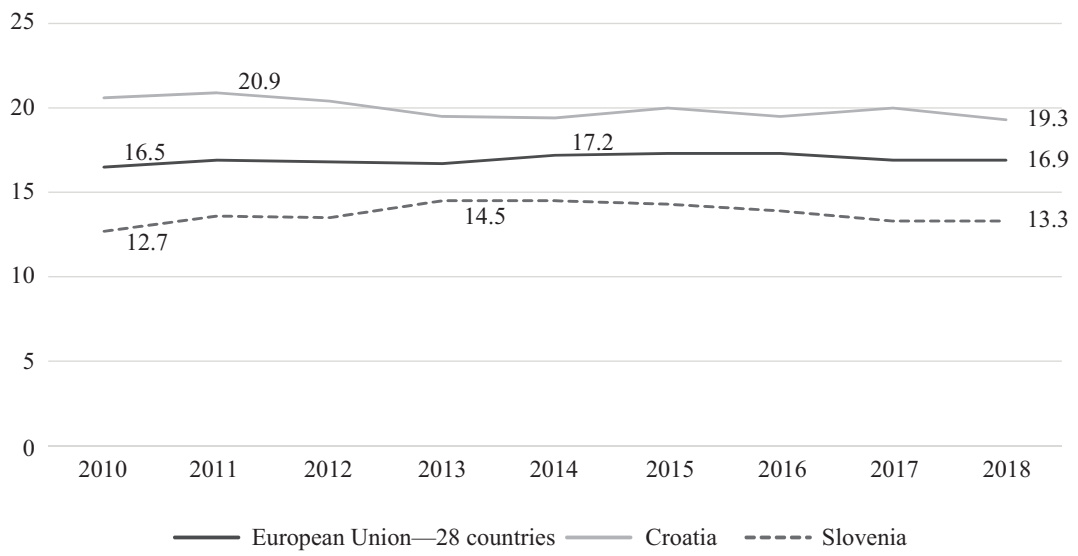

Graph 10. At risk of poverty rate dynamics HR, SLO and EU 28

Source: Eurostat, 2019.

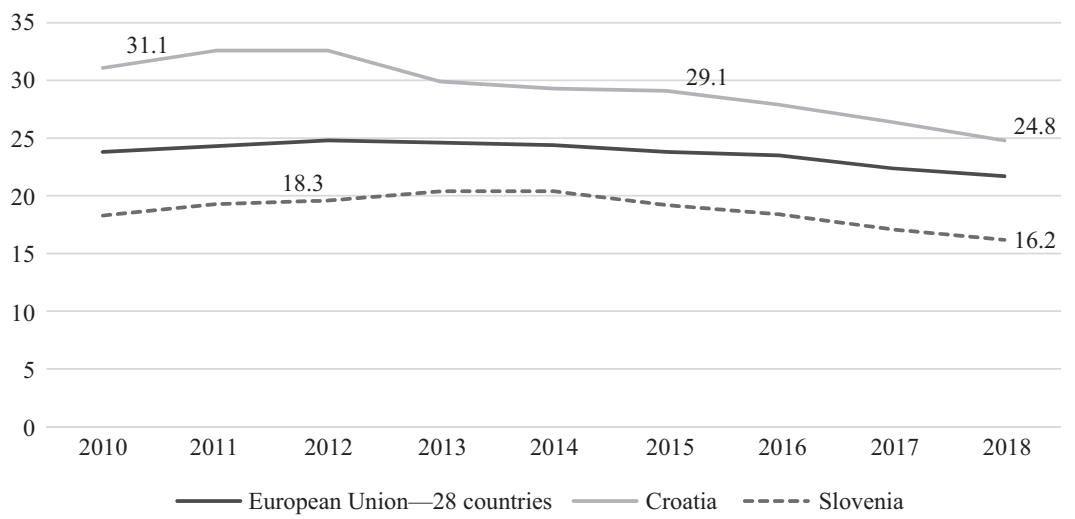

Graph 11. At risk of poverty rate and social exclusion dynamics HR, SLO and EU 28

Source: Eurostat, 2019. 
As it could be seen from the data presented in graph 10 and 11 in Croatia in the 2010-2018 period, the at risk of poverty rate has fluctuated around $20 \%$ ending with $19.3 \%$ in 2018 while in Slovenia the at poverty risk rate has fluctuated between $13 \%$ and $14.5 \%$ ending with $13.3 \%$ in 2018 . It is clear from the data presented that the at risk of poverty rate is continuously around 6 percentage points higher in Croatia than in Slovenia. Moreover, the differences are even higher when we compare the proportions of population exposed to poverty and social exclusion risks which in Croatia started at $31.1 \%$ and in Slovenia at $18.3 \%$ in 2010 and in Croatia due to positive economic trends from 2015 ended with $24.8 \%$ in 2018 and in Slovenia at 16.2\%—-still representing a difference of more than 8.5 percentage points.

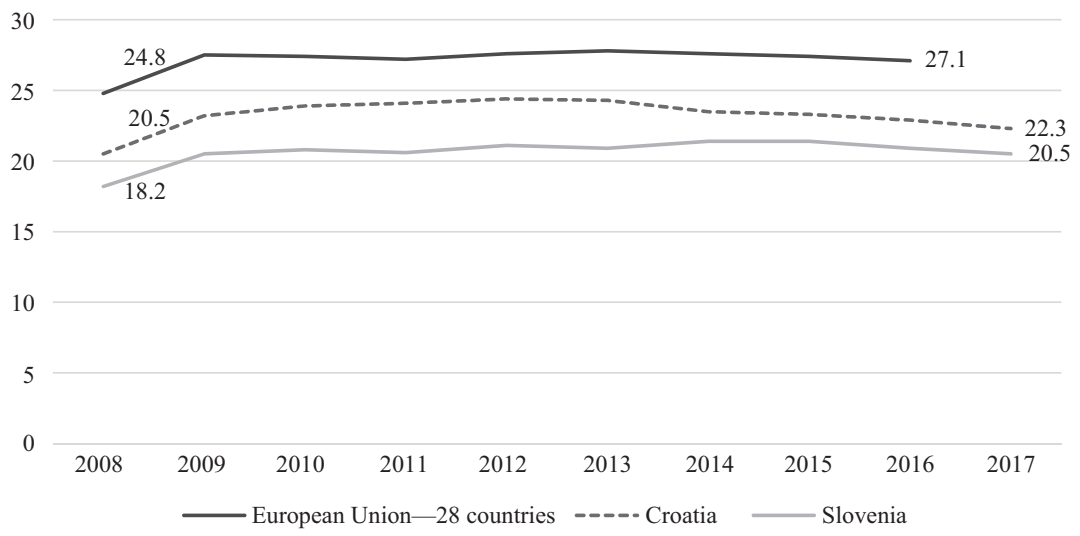

Graph 12. Social protection expenditure in EU, SLO and HR

Source: Eurostat, 2019.

This difference can be better ascribed to higher economic inequality in Croatia described above (having in mind the relative methodology for the measurement of poverty risk) rather than to a lower level of economic development. Also, continuously lower aggregate expenditure on social protection in Croatia than in Slovenia (see graph 12) is particularly important for social exclusion data, implying a better structured system of social protection in Slovenia than in Croatia, with generally higher and more generous social benefits.

\section{Effectiveness of the social transfer system in alleviating poverty in Croatia and Slovenia}

The previous section showed that Slovenia had a significantly lower at risk of poverty rate than Croatia due to continuously lower registered economic inequalities in the past decade. That fact is just one piece of the puzzle in explaining why Croatia continuously registered a significantly higher at risk of poverty rate than Slovenia. To get a better 
picture, it is important to also analyse factors such as effectiveness in the social transfer, social assistance, and minimum income systems, and their impact on the at risk of poverty rate in both countries. Aforementioned indicators for Slovenia and Croatia will be presented in the following part of the text in order to investigate whether the level and effectiveness of the social transfer in general and especially social assistance system could be 'blamed' too for a significantly higher at risk of poverty rate in Croatia. To gauge the impact on poverty alleviation the data on the poverty risk pre- and post- social transfer is often used. This data is available for both countries in the Eurostat data-base and is presented in table below. Data presented in table 3 suggests that the at risk of poverty rates before social transfers in 2005 and 2018 were very close in Slovenia and Croatia, but post transfer at risk poverty rates differ significantly due to the impact of social transfers which are obviously more effective in poverty alleviation in Slovenia. Overall, data in table 3 suggests that the social transfers in Slovenia were more effective in poverty alleviation than the Croatian system of social transfers in the last fifteen years.

Table 3. At risk poverty rate in Slovenia and Croatia before and after social transfers

\begin{tabular}{|l|c|c|c|c|c|c|}
\hline \multicolumn{1}{|c|}{ Year } & $\mathbf{2 0 0 5}$ & $\mathbf{2 0 1 0}$ & $\mathbf{2 0 1 2}$ & $\mathbf{2 0 1 4}$ & $\mathbf{2 0 1 6}$ & $\mathbf{2 0 1 8}$ \\
\hline $\begin{array}{l}\text { Poverty rates } \\
\text { before social transfers in SLO \% }\end{array}$ & 25.9 & 24.2 & 25.2 & 25.1 & 24.3 & 23.4 \\
\hline $\begin{array}{l}\text { Poverty rates } \\
\text { after social transfers in SLO\% }\end{array}$ & 12.2 & 12.7 & 13.5 & 14.5 & 13.9 & 13.3 \\
\hline Poverty rates alleviation effect in SLO \% & 13.7 & 11.5 & 11.7 & 10.6 & 10.4 & 10.1 \\
\hline $\begin{array}{l}\text { Poverty rates } \\
\text { before social transfers in CRO }\end{array}$ & 26.0 & 30.2 & 30.6 & 29.9 & 27.3 & 25.7 \\
\hline $\begin{array}{l}\text { Poverty rates } \\
\text { after social transfers in CRO }\end{array}$ & 18.0 & 20.5 & 20.4 & 19.4 & 19.5 & 19.3 \\
\hline Poverty rates alleviation effect in CRO \% & 8.0 & 9.7 & 10.2 & 10.5 & 7.8 & 6.4 \\
\hline
\end{tabular}

Source: Eurostat database.

The efficiency of social transfers has been an important topic in the Slovenian research and policy making (Stanovnik, Stropnik, 1998; Stropnik, Stanovnik, 2002; Kump, Stropnik, 2009; Stropnik, 2010). On the other hand, social transfers and their impact on economic inequality and poverty in Croatia is a relatively new and rare 'topic' among researchers and policy makers. The first research about the impact of social transfers on poverty in Croatia was conducted by Šucur (2005), and he found that the total system of social transfers was not less effective than the European average at that time. However, aforementioned research (ibid) showed that the poverty rate reduction due to old age and survivor pensions was one of the lowest in EU countries. The next research was conducted by Babic (2008) and showed that the Croatian system of social transfers is contributing to both poverty and economic inequality reduction, but the efficiency of the system was 
below European average at that time. On the other hand, research from Slovenia showed that efficient targeting and relatively high level of benefits redistribute income significantly and decrease poverty and income inequality in Slovenia (Kump and Stropnik, 2009) and Stropnik (2010) showed that social transfers in Slovenia are effective and among the best performers in alleviating child poverty in Europe. A relatively new comparative study about income redistribution through taxes and benefits in Slovenia and Croatia (Čok et al., 2013) using household budget survey data for Croatia and administrative data from the Statistical office for Slovenia also found that Croatia experienced significantly higher pre-fiscal income inequality and achieved a lower redistributive effect from the social transfer system than Slovenia.

Presented data and research results imply that the effectiveness of the social transfer system is the second important explanatory variable for the continuously higher at risk of poverty rates in Croatia compared to Slovenia. Namely, it is obvious from the data presented in table 3 and from research results that the social transfer system in Slovenia redistributes more and is more effective in poverty alleviation than in Croatia. The next logical question is which factors lie behind the fact that the Slovenian social transfer system is more effective in poverty alleviation than Croatian ones. We can partially answer this question by comparing the minimum income scheme in Slovenia and the social assistance system in Croatia as instruments which are mainly directed towards the poor. Namely, research findings suggest that vertical redistribution is connected with the level of total social transfers but also with compositions of the social transfer system where social assistance and means tested benefits include much stronger elements of vertical redistribution (Nelson, 2012).

A number of research papers in Croatia stated that protection of the poor population in Croatia is rather low due to a) low level of the transfers aimed directly at the poor (2007 and 2010) b) lower efficiency in the social transfer system (Babić, 2008). One way to get an insight into how the poor are protected in Croatia is to compare the level of protection of the poor in Croatia with the protection of the poor in other countries-in our case with Slovenia. On the basis of the indicators presented in table 4, it can be concluded that Croatia has had a significantly lower coverage rate of the poor using the social assistance scheme than Slovenia. 9.3 percent of the people under the at risk of poverty rate threshold in Croatia were receiving social assistance benefits in 2018 compared with the much higher 19.3 percent in Slovenia. The Croatian position is even worse regarding the adequacy level of social assistance benefits.

The European Parliament (2009) stated that the adequate minimum income should reach at least the at-risk-of poverty threshold agreed by the EU Member States. It is evident from the data and indicators presented in the table 4 that the Croatian system of the poor population protection is lagging behind Slovenian minimum income and also the European Parliament "benchmarks". Namely, as indicators in the table suggest, Croatian social assistance benefits with 23 percent of adequacy rate is significantly lagging behind compared to some 48 percent adequacy rate of minimum income in Slovenia in 2018. The data in table 4 also reveals that these differences between Slovenia and Croatia are 
roughly stable in the last ten years and it is clear that the Slovenia minimum income protection system is more adequate in terms of coverage and adequacy rate resulting in better poverty alleviation capacity.

Table 4. Coverage rate and adequacy rate of social assistance and minimum income in Croatia and Slovenia

\begin{tabular}{|c|c|c|c|c|c|c|c|}
\hline & 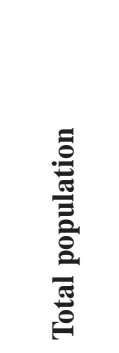 & 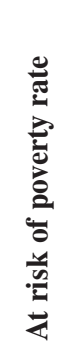 & 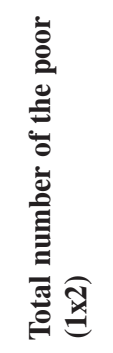 & 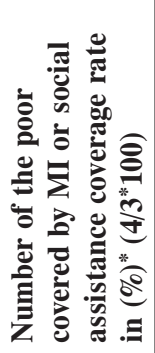 & 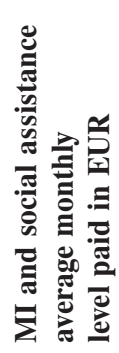 & 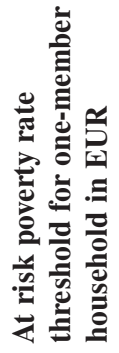 & 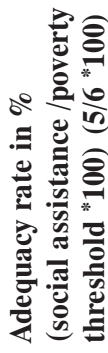 \\
\hline & 1 & 2 & 3 & 4 & 5 & 6 & 7 \\
\hline Croatia 2007 & 4435982 & 17.4 & 771860 & $\begin{array}{l}102953 \\
(13.3 \%)\end{array}$ & 51 & 263 & 19.4 \\
\hline Croatia 2010 & 4417781 & 20.5 & 905645 & $\begin{array}{l}102668 \\
(11.3 \%)\end{array}$ & 58 & 288 & 20.1 \\
\hline $\begin{array}{l}\text { Croatia } 2018 \\
\text { (or most recent) }\end{array}$ & 4076246 & 19.3 & 786715 & $\begin{array}{c}72759 \\
(9.3)\end{array}$ & 75 & 333 & 23.0 \\
\hline Slovenia 2007 & 2025866 & 11.5 & 232974 & $\begin{array}{c}43600 \\
(18.7 \%)\end{array}$ & 204 & 495 & 41.2 \\
\hline Slovenia 2010 & 2046576 & 12.7 & 259915 & $\begin{array}{c}48700 \\
(18.7 \%)\end{array}$ & 226 & 587 & 38.5 \\
\hline $\begin{array}{l}\text { Slovenia } 2018 \\
\text { (or most recent) }\end{array}$ & 2056153 & 13.3 & 273468 & $\begin{array}{l}52955 \\
(19.3)\end{array}$ & 318 & 662 & 48.0 \\
\hline
\end{tabular}

Sources: Eurostat, Statistical offices of Croatia and Slovenia, Croatian Ministry for Social Policy and Youth data base, Slovenia Ministry of Labour, Family and Social Affair coverage rate poor covered by MI or social assistance as a $\%$ in total number of the poor.

\section{Conclusions}

Our first section has shown a brief historical overview of economic tendencies in Slovenia and Croatia and pointed out that the two economies remained at approximately the same levels of development until the late eighties, in the socialistic period (with Croatia at roughly $90 \%$ of the Slovene GDP per capita levels). These levels diverged substantially in the early transition period as a result of extremely unfavourable conditions in Croatia in the context of a destructive, four-year war. Some of the lost ground has been recovered, but the Croatian economy has failed to re-converge, although several decades 
have now passed. We have looked for reasons in the second and third sections. Section 2 has compared the elementary market organizing institutions (labour and finance) in Slovenia and Croatia with those found in the four successful post-socialist economies of the Visegrád group. We have found notable similarities in Croatia and Slovenia, particularly when compared to Visegrád countries. However, we have also pointed out that these are marred by the unfortunate institutional tendencies of clientelism in Croatia, subverting economic efficiency through a public sector which leaves much to be desired.

Section "Institutions of capitalism in Slovenia and Croatia" looked for additional structural reasons through the analysis of growth models in Croatia and Slovenia. We have found that Slovenia is far more industrialized on the supply level, and has a more favourable demand structure as its current account tends to be in a better overall position, while Croatia is somewhat more oriented towards services on the level of supply and has a more pronounced private consumption-led demand. These structural tendencies offer some semblance of compatibility with the institutional outline of section "Brief economic history of Croatia and Slovenia", as services in Croatia are marked primarily by the very large tourism sector, offering seasonal employment and rent-seeking behaviour by realestate owners on the coast, which is particularly attractive to tourists. These may both be compatible with the clientelist mentality. Likewise, the strong industrial base in Slovenia has given a functional foundation to more comprehensive coordination in industrial relations with economically felt results. Of course, on both counts, we can point only to a potential complementarity rather than a causal relation.

Section "Growth models in Croatia and Slovenia" has opened the crucial issue of social policy and social consequences in our comparison. Slovenia has a strong tradition of social inclusion, with its Gini coefficient and economic inequality being the lowest among EU member countries for years. In contrast, poverty and social exclusion are significant problems in Croatia. Whereas the income quintile share ratio (S80/S20) and the Gini coefficient broadly match the EU 28 average, around 1 million or $24.8 \%$ of the Croatian population is at risk of poverty or social exclusion, a figure significantly higher than the EU 28 average. The trends concerning these indicators are, however, slightly positive: the income quintile share ratio (S80/S20) decreased from 5.6 in 2011 to 5.0 in 2018, while the Gini coefficient decreased from 31.6 in 2010 to 29.7 in 2018. The material and social deprivation rate (i.e., when households cannot afford at least five of the 13 items taken into account) also decreased from $22.3 \%$ down to $14.7 \%$ in $2017,10.3 \%$ of the population live in conditions of severe material deprivation while in Slovenia the respective figure is $4.6 \%$.

From the data presented above it is a clear that poverty and social exclusion trends and the differences between Slovenia and Croatia have stood at almost the same level for the past fifteen years. This is despite the fact that general economic and social trends in Croatia are positive since the recovery from the recession began in 2015. On the other hand, as the analysed data suggests, there are almost no changes in terms of reducing social indicator disparities between Croatia and Slovenia which persist and have been 
stable for the last fifteen years. Croatia in 2018 registered significantly higher economic inequality and poverty and social exclusion risks than Slovenia which is mainly the result of the lack of improvement in social policy creation and implementation in Croatia, proving our hypothesis. Namely, as we showed by the analysis in the text, Slovenia has a better organized and more generous system of social benefits than Croatia, which is reflected in a better targeting and coverage of the poor population with benefits which are generally and relatively higher than in Croatia with a higher adequacy rate. On the other hand, the social transfers system in Croatia suffers from significant fragmentation and is not structured in such a way that they can have any significant impact on social exclusion. Benefits are very low and eligibility criteria are tight, as recipients must not own anything except an apartment in which they live (i.e. no car or savings).

In an effort to address these issues, the government has begun drafting a new Social Welfare Act, planned for 2019. This is an opportunity for a significant increase in the social assistance benefits system and we can only express hope that the social transfer system aiming at poverty alleviation will be significantly improved. If this does not prove to be the case, one cannot expect improving living prospects for those at the bottom while by social indicators Croatia will be further at the end of EU countries.

\section{References}

Babić, Z. (2008). Redistribucijski učinci sustava socijalnih transfera u Hrvatskoj. Revija za socijalnu politiku, 15(2): 151-171.

Becker, U. (2007). Open systemness and contested reference frames and change. A reformulation of the varieties of capitalism theory. Socio-Economic Review, 5(2): 261-286.

Bićanić, I., Franičević, V. (2005). The Challenges of Real and Subjective Poverty and the Growth of Inequality in the Economies of South Eastern Europe in Transition. Financial Theory and Practice, 29(1): 13-16.

Bolt, J., Inklaar, R., de Jong, H., van Zanden, J. L. (2018). Rebasing 'Maddison': new income comparisons and the shape of long-run economic development. GGDC Research Memorandum, 174.

Čok, M., Urban, I., Verbič, M. (2013). Income redistribution through taxes and social benefits: the case of Slovenia and Croatia. MPRA working paper 38918. University Library Munich.

Cvijanović, V., Redžepagić, D. (2011). From political capitalism to clientelist capitalism? The case of Croatia. Zbornik radova Ekonomskog fakulteta u Rijeci: časopis za ekonomsku teoriju i praksu, 29(2): 355-372.

Družić, G. (2009). Croatian Economic Development and EU: Potential and Perspectives. Zagreb: Školska knjiga.

European Commission. (2014). Investment for jobs and growth. Promoting development and good governance in EU regions and cities. Sixth Report on Economic, Social and Territorial Cohesion. Luxembourg: Publication Office of the European Union. 
European Parliament (2009). Active Inclusion of People Excluded from the Labour Market, 2008/2335(INI). Brussels: European Parliament.

Eurostat (2019). Database. https://ec.europa.eu/eurostat/data/database. Accessed: 21.9.2019

Franičević, V. (2002). Politička i moralna ekonomija u prvom desetljeću tranzicije u Hrvatskoj. Politička misao, 39(1): 3-34.

Hall, P. A., Gingerich, D. W. (2009). Varieties of capitalism and institutional complementarities in the political economy: An empirical analysis. British Journal of Political Science, 39(3): 449-482.

Hall, P. A., Soskice, D. (2001). Varieties of Capitalism. Oxford University Press.

Hanžek, M., \& Gregorčić M. (2001). Human Development Report Slovenia 2000-2001. Institute of Macroeconomic Analysis and Development, Ljubljana. Available at: http:// www.umar.gov.si/fileadmin/user_upload/projekti/hdr2000.pdf

Holzner, M., Leitner, S. (2008). Economic Inequality in Central, East and Southeast Europe. wiiw Balkan Observatory Working Papers 74, The Vienna Institute for International Economic Studies, wiiw.

IMF (2019). World Economic Outlook database, April 2019. https://www.imf.org/external/ pubs/ft/weo/2019/01/weodata/index.aspx. Accessed 1.10.2019

Ivanković, Ž. (2017). Slučaj Agrokor: Privatizacija i crony kapitalizam. Zagreb: Jesenski i Turk. Kump, N., Stropnik, N. (2009). Reducing and preventing child poverty and social exclusion in Slovenia-Lessons learned from transition countries. Report for UNICEF. Ljubljana: Institute for Economic Research.

Lučev, J., Babić, Z. (2013). Tipovi kapitalizma, ekspanzija neoliberalizma i socijalni učinci u baltičkim zemljama, Sloveniji i Hrvatskoj: komparativni pristup. Revija za socijalnu politiku, 20(1): 1-20.

Maddison Project (2018). Maddison Project Database 2018. https://www.rug.nl/ggdc/ historicaldevelopment/maddison/releases/maddison-project-database-2018. Accessed: 15.11.2019

Mencinger, J. (2002). The benefits of ignoring IMF. Ekonomski pregled, 53(3-4): 391-403. Avialble at: https://hrcak.srce.hr/index.php?show=clanak\&id_clanak_jezik=

Milanovic, Branko, 1998, Income, Inequality and Poverty during the Transition from Planned to Market Economy. The World Bank, Washington D.C.

Nelson, K. (2012). Counteracting material deprivation: The role of social assistance in Europe, Journal of European Social Policy, 22 (2): 148-163.

Nölke, A. (2016). Economic causes of the Eurozone crisis: the analytical contribution of Comparative Capitalism. Socio-Economic Review, 14(1): 141-161.

Nölke, A. (2019). In Search of Institutional Complementarities: Comparative Capitalism and Economic Policy Reform, Journal of Economic Policy Reform: 1-8.

North, D. C. (1991). Institutions. Journal of Economic Perspectives, 5(1): 97-112.

Petak, Z. (2019). Policy-Making Context and Challenges of Governance in Croatia. In: Z. Petak, K. Kotarski (eds), Policy-Making at the European Periphery. Cham: Palgrave Macmillan. 
Rončević, B. (2001). Socijalna situacija i socijalne reforme u Sloveniji. Revija za socijalnu politiku, 8(2): 131-157.

Šimić Banović, R. (2019). Uhljeb-a post-socialist homo croaticus: a personification of the economy of favours in Croatia? Post-Communist Economies, 31(3): 279-300.

Šimončić-Bobetko, Z. (2005). Industrija Hrvatske 1918. do 1941. godine. Zagreb: AGM.

Stanovnik, T., Stropnik N. (1998). Impact of Social Transfers on Poverty and Income Inequality in Slovenia: A Comparison between the Pre-Transition and the Post-Transition Period. Ljubljana: Institute for Economic Research.

Streeck, W. (2010). Institutions in History: Bringing Capitalism Back in. In: G. Morgan, et al. (eds), The Oxford Handbook of Comparative Institutional Analysis. Oxford: OUP. Stropnik, N. (2010). Policy overview and policy impact analysis-A case study: Slovenia. In: Child poverty and child well-being in the European Union. Volume IV: Country case studies. Report prepared for the DG Employment, Social Affairs and Equal Opportunities (Unit E.2) of the European Commission. Budapest: TÁRKI.

Stropnik, N., Stanovnik T. (2002). Combating Poverty and Social Exclusion-Volume 2, A Case Study of Slovenia. Budapest: International Labour Office.

Stubbs, P., Zrinščak, S. (2015). Citizenship and social welfare in Croatia: Clientelism and the limits of 'Europeanisation'. European Politics and Society, 16(3): 395-410.

Šucur, Z. (2005). Siromaštvo i socijalni transferi u Hrvatskoj. Financijska teorija i praksa, 29(1): 37-58.

Thijs, N., Hammerschmid, G., Palaric, E. (2018). A comparative overview of public administration characteristics and performance in EU28. Luxembourg: Publications Office of the European Union. https://ec.europa.eu/social/BlobServlet?docId=19208\&langI$\mathrm{d}=$ en. Accessed 15.11.2019

Visser, J. (2019). ICTWSS: Database on Institutional Characteristics of Trade Unions, Wage Setting, State Intervention and Social Pacts in 55 countries between 1960 and 2018. http:// uva-aias.net/en/ictwss. Accessed 13.11.2019

Vojnić, D. (2013). Ekonomija i politika tranzicije-pola stoljeća povijesti reforme socijalizma i tranzicije 1962.-2012. u svjetlu novije ekonomske povijesti. Rad HAZU: Razred za društvene znanosti, (50): 153-186.

World Bank (2019). Data Bank. https://databank.worldbank.org/. Accessed: 1.10.2019

\section{Streszczenie}

Republika Chorwacji i Republika Słowenii od stuleci mają wspólną historię polityczną i gospodarczą. Historycznie Słowenia była bardziej rozwinięta, ale Chorwacja pod koniec lat osiemdziesiątych XX w. zbliżyła się do Chorwacji pod względem podstawowych wskaźników ekonomicznych i społecznych. W ciągu kolejnych trzech dekad nierówności gospodarcze i społeczne między Chorwacją a Słowenią znacznie wzrosły i obecnie te dwa kraje znajdują się pod wieloma względami na przeciwległych krańcach wśród członków UE. Artykuł potwierdza klasyczne wyjaśnienia tego stanu, wskazując m.in. na negatywny wpływ 
wojny domowej w Chorwacji w latach 1991-1995 oraz członkostwo Słowenii w UE od 2004 r., podczas gdy Chorwacja może czerpać korzyści z członkostwa w UE dopiero od 2013 r. Artykuł wykracza jednak poza te dwa argumenty i proponuje dodatkowe zmienne wyjaśniające dla rozbieżnych tendencji w sferze gospodarczej i społecznej. Analizuje specyfikę instytucjonalną Chorwacji i Słowenii (porównując je z krajami wyszehradzkimi), modele wzrostu oraz sposób realizacji polityki społecznej od czasu transformacji w obu tych krajach. Dowodzi, że za rozbieżne tendencje w Chorwacji i Słowenii odpowiada w dużym stopniu sposób przygotowania i wdrożenia polityki gospodarczej i społecznej w tych dwóch krajach.

Słowa kluczowe: gospodarki postsocjalistyczne, Słowenia, Chorwacja, reformy instytucjonalne, polityka społeczna 